\title{
The Origin of the Idea That Herpes Labialis Is of Prognostic Importance in Bacterial Meningitis
}

\author{
Peter J. Koehler \\ Faculty of Health, Medicine and Life Sciences, Maastricht University, Wijlre, The Netherlands
}

\author{
Keywords \\ Herpes simplex - Bacterial meningitis - Prognosis . \\ Diagnosis $\cdot$ History of medicine
}

\begin{abstract}
Objective: The aim of the work was to study the origin of the idea that herpes labialis $(\mathrm{HL})$ in patients with pneumonia and meningitis was believed to be of prognostic importance. Background: $\mathrm{HL}$ is caused by a primary infection or reactivation of herpes simplex type I. In the past, it has been related to pneumonia and meningitis; moreover, $\mathrm{HL}$ was believed to be of prognostic importance. Methods: A selection of 19thand 20th-century textbooks and referred articles was consulted. The relation between meningitis and herpes, type of meningitis, and attributed diagnostic and prognostic importance were studied. In addition, the HL-pneumonia association was studied. Results: The Strasbourg physician CharlesPolydore Forget was the first to describe the HL-meningitis association in 1843. Tourdes (1843), Drasche (1859), and Salomon (1864) attributed a favorable prognostic importance to the HL-meningitis relation. In a comprehensive monograph (1866), August Hirsch, although confirming the association, denied the prognostic importance through critical analysis of the data. Few authors attributed a diagnostic importance to the occurrence of $\mathrm{HL}$, suggesting meningococcal meningitis. Conclusions: The HL-meningitis relation, but
\end{abstract}

not the prognostic importance, has been mentioned in most neurological textbooks since then. In contrast to meningitis, in which a prognostic attribution of HL was only a short-lived 19th-century idea, the favorable prognostic importance of $\mathrm{HL}$ in pneumonia continued to be described until the 1950s. A possible protective effect of herpesviruses has been found in recent years. One could speculate that the disappearance of the prognostic $\mathrm{HL}$-pneumonia relation could be related to the introduction of antibiotics in the late 1940s.

(c) 2020 The Author(s)

Published by S. Karger AG, Basel

\section{Introduction}

Herpes labialis (HL) is a well-known condition caused by a primary infection or reactivation of herpes simplex type I, the latter occurring in $20-40 \%$ of the infected population. The English physician Richard Morton (16371698) [1] is usually mentioned as one of the first to describe herpes febrilis. He did not describe the location but noted the relation with febrile conditions. Moreover, he wrote that fevers accompanied by herpes were always the mildest and always benign [1]. The idea of associating a prognostic importance in febrile conditions with the appearance of HL has turned up in several texts of the 19th century, perhaps the best known being William Osler 
(1849-1919) [2]. With respect to HL and pneumonia, he noted that "it is supposed to be of favorable prognosis, and figures have been quoted in proof of this assertion" [2, p. 521]. He also described the relation of HL with meningitis. "Herpes labialis occurs with even greater frequency than in pneumonia or intermittent fever" [2, p. 95]. In the present article, the history of the relation between meningitis and HL, in particular the ideas of attributing a diagnostic and a prognostic importance, was studied.

\section{Methods}

A selection of textbooks (English, German, French, and Dutch) was consulted, in which texts referring to meningitis and to herpes were read. In order to secure a representative list of books, commonly known medical and neurological books in English, German, and French language from two standard books, notably Garrison's History of Neurology and the "Diseases of the nervous system" section in Morton's Medical Bibliography, were selected [3, 4]. Moreover, three main multivolume neurological handbooks of the 20th century were consulted [5-9]. The following issues were noted: the relation between meningitis and herpes, type of meningitis, diagnostic importance, and prognostic importance. Although most consulted books concern neurological textbooks, some general medical textbooks were added, where the HL-pneumonia association was studied in addition. Furthermore, a number of referred articles were consulted, in which bacterial meningitis, mainly epidemic (meningococcal) meningitis, was reported. An important source for these articles was August Hirsch's (1866) [10] monograph on epidemic cerebrospinal meningitis. The period of search was limited to the 19th and early 20th centuries for reasons with respect to the identification of HL (problems with term-condition association), as well as with respect to diagnosing bacterial meningitis, which also gradually came to the foreground in the course of the 19th century [11]. Quotes were translated by the present author.

\section{Results and Discussion}

The results with respect to author, year of publication, mentioning of the herpes (labialis)-meningitis association, type of (bacterial) meningitis, diagnostic importance, and prognostic factor attribution are displayed in Table 1. Books and journal articles are displayed separately. In the following text, some of the remarkable features that were found in the various chapters and articles are discussed.

\section{HL-Meningitis Relation}

Gaspard Vieusseux (1746-1814) [12], considered the first to describe epidemic bacterial meningitis, did not mention herpes. Remarkably, the voluminous mono- graph on "inflammation of the arachnoid" by ParentDuchatelet and Martinet (1821) [13] does not refer to herpes (by this term or by any other designation), although it does discuss skin changes. The textbook by the well-known French internist Armand Trousseau (18011867) [14] does not mention the herpes-meningitis association but does refer to the herpes-pneumonia association.

The first to mention the herpes-meningitis association in a book was the German physician August Hirsch (1817-1894) [10]. He provided "historic-geographical and pathologic-therapeutical standpoints" on a disease he was concerned about and much in need of more scientific knowledge. He wrote:

By far the most frequently appears the exanthema in the form of herpes...; in some epidemics this exanthema was of an unusual frequency, in this way amongst others Tourdes noticed it in two third of all cases observed by him, ... whereas in other epidemics it was observed only sporadically [10, p. 75].

Although not necessarily because of this monograph, the herpes-meningitis association has been mentioned in most textbooks since 1866. The 19th-century authors on the relationship (Hirsch and Tourdes) took meningitis as a starting point and looked at the occurrence of associated symptoms, including HL. They did not mention the frequency in other feverish diseases, as their publications were particularly on meningitis, so it cannot be stated whether they saw it in other infections too. The same is true for most neurology textbooks presented in Table 1.

\section{Type of (Bacterial) Meningitis}

Recognizing today the diagnosis of bacterial meningitis in texts published prior to 1800 is quite difficult as these texts were still written in terms of the ancient humoral pathophysiology [11]. Even the Strasbourg physician Gabriel Tourdes (1810-1900) [15] experienced difficulties recognizing previous epidemics. However, the epidemic occurrence and the description of the symptoms and signs are very suggestive of meningococcal meningitis. After the 1866 publication by Hirsch, mentioned in the previous section, most textbooks mention the herpes-meningitis relation, aiming at the epidemic cerebrospinal meningitis, which today we would call meningococcal meningitis. Only one mentions the relation in "bacterial meningitis" in general, but it does not particularly mention that is also seen in other types of bacterial meningitis [9]. Meningococcus was discovered in 1887 [11]. 
Table 1. HL related to bacterial meningitis in textbooks and relevant articles $[1,2,7-10,14-26,28-50]$

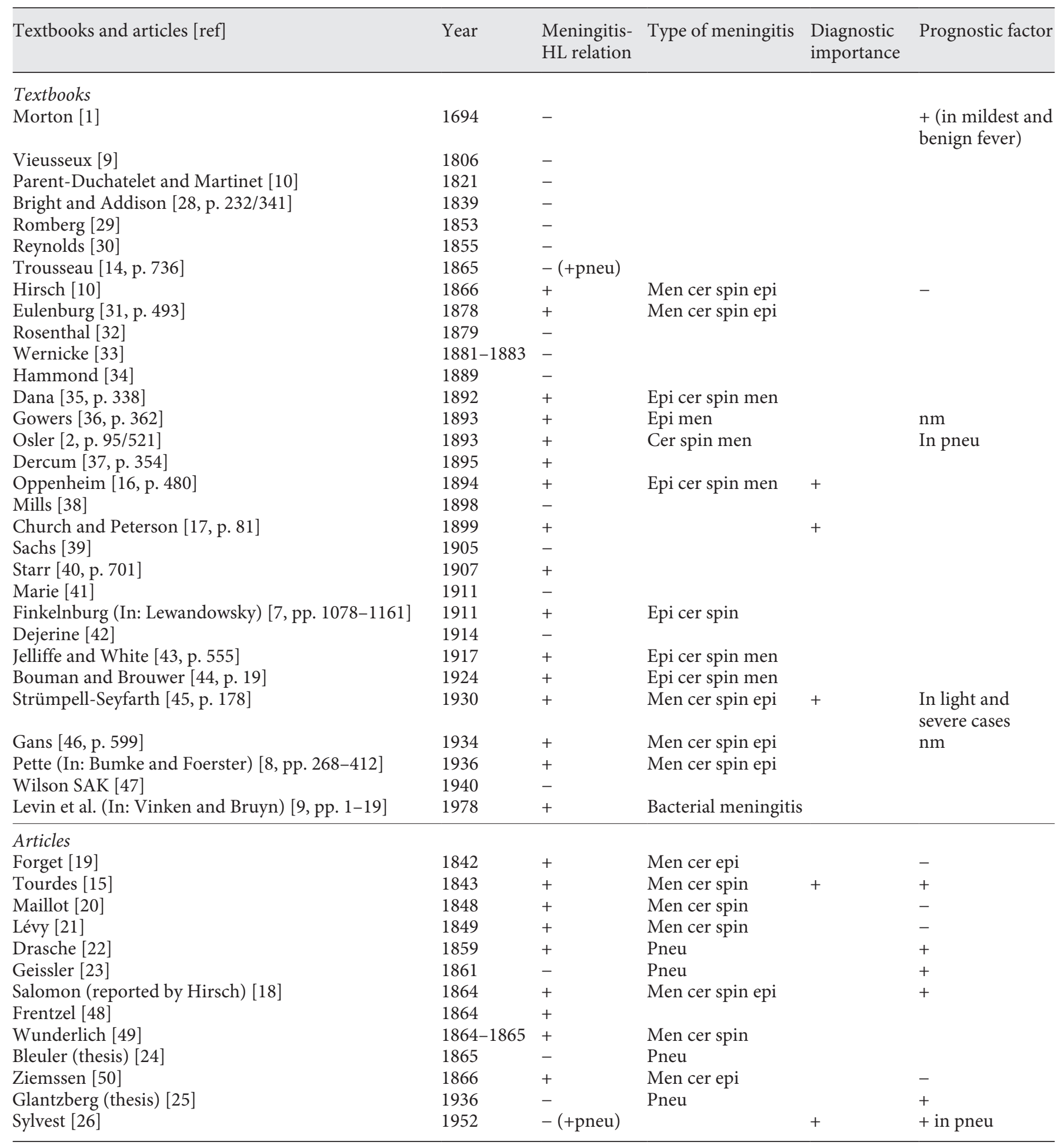

Cer, cerebral; epi, epidemic; men, meningitis; pneu, pneumonia; spin, spinalis; nm, not mentioned. 


\section{Diagnostic Importance}

An interesting issue with respect to the herpes-meningitis relation is the fact that some authors refer to a diagnostic importance of the appearance of HL. Hirsch used the term "pathognomisch" [10, p. 76]. After him, the Berlin neurologist Hermann Oppenheim (1858-1919) [16] was one of the first to point to it in a neurological textbook.

Very often and early rash occurs ... Of diagnostic significance in particular is herpes, which as a rule appears already in the first days. The vesicles are predominantly located on the lips, often also in the face, the ears and in a symmetric way on the extremities. There are epidemics, in which herpes is among the signs in all cases [16, p. 480].

Another example is Heinrich Pette (1887-1964) [8] in the 1930s, who wrote:

Important in particular also with respect to the diagnosis, are the skin phenomena, in the first place herpes labialis respectively facialis. It appears in about $75 \%$ of all cases and in contrast to other situations it is characterized by its unusually large extension. It extends from the lips, often to the nose, cheeks and forehead $[8, \mathrm{p}$. 342].

Church and Peterson wrote: "herpes labialis is as common as in pneumonia and as significant" [17, p. 81].

\section{HL as a Prognostic Factor in Meningitis}

A more interesting issue is whether the appearance of $\mathrm{HL}$ is of prognostic importance. With respect to textbooks, Hirsch was the first to discuss this issue at length and apparently was not in favor of the attribution of a prognostic significance to the appearance of HL in meningitis, critically reviewing a number of articles that discussed the possible relationship [10, p. 76]. His view was based upon the publications that are listed in Table 1, published between 1842 and 1866. Tourdes [15], in particular, was the first physician to attribute a favorable prognostic importance to the appearance of HL. Professor of forensic medicine in Strasbourg, he estimated the number of meningitis cases among the civil population at approximately 230, of whom 90 died. Two-thirds had HL, and he considered it as one of the characteristic signs of the disease [15, p. 108]. Moreover, he believed this to be an argument in favor of the existence of a special miasma, at the time a well-known theory explaining epidemics of diseases such as cholera, caused by a noxious form of bad air. For 31 patients, Tourdes knew the period in which it erupted: in 6 cases on day 2 or 3 , in 24 cases on days 4 to 7 , and in only 1 patient on day 8 , never later. Day 4 (9 cases) and day 7 ( 7 cases) were the most frequent. Of these 31 cases, 15 died, and although this figure is not much different from the general mortality from the disease, he noticed:

The most extensive eruptions have been found in favorable cases; the 3 patients in whom the vesicles occupied at a certain time the lips, the cheeks, the brows and the thorax, have been saved. In many mortal cases, in contrast, the eruption hardly showed, it was limited to some vesicles at the corners of the lips [15, p. 113].

Therefore, he attributed a favorable prognosis to the extensive spread of herpes, beyond the lips. He also noticed that if the eruption occurred between the fourth and the sixth day, it had a favorable prognosis $(6 / 17$ mortal vs. 10/14 if early or late), but he was aware of the relatively small numbers. Although it is not the purpose of this work to study this, Tourdes made an important observation, notably that "lenticular spots and petechiae are the signs of the greatest danger; they do not occur but in the mortal cases" [15, p. 114]. A second physician from the period, who attributed favorable prognoses to herpes eruptions, was Salomon, who corresponded with Hirsch, the latter publishing the communication in 1865. Elias Salomon (1814-1885) reported on the epidemic (1863-1864) in the Prussian city of Bromberg (the present Bydgoszcz in Poland), where 363 adults (11 deaths) and 659 children (51 deaths) were observed (which is remarkably low in the pre-antibiotic era and compared, e.g., with the figures reported by Tourdes). "Exanthemas were observed in several forms, notably in the form of HL, after the occurrence of which in some cases the phenomena disappeared, resulting in a fast cure" [18].

In contrast, other authors were unable to observe a favorable prognostic sign with respect to the occurrence of HL. Charles-Polydore Forget (1800-1861) [19], professor of pathology and medical clinic at the University of Strasbourg, observed it in almost all cases, in those who recovered as well as those who died, and was unable to attribute it a prognostic sign. Another French physician, François-Clémence Maillot (1804-1894) [20], at the time practicing in a military hospital in Lille, wrote that "the cases of HL did not bring any change in the course of the phenomena." Michel Lévy (1809-1872) [21], practicing at the Paris military hospital of Val-deGrâce, observed HL in about 13\%; of the 8 cases, 6 were mortal. He opposed the conclusions made by Tourdes. Following these negative reports with respect to the denial of a favorable prognostic attribution to the occurrence of HL, no new positive correlations with meningitis have been identified. However, with respect to pneumonia, the attribution of a favorable outcome seems to have continued. 


\section{HL and Pneumonia}

With respect to the attribution of a favorable prognosis of the occurrence of HL in pneumonia, Anton Drasche (1826-1904) [22], who practiced at the Allgemeine Krankenhaus in Vienna, observed HL in $40 \%$ of pneumonia cases, in light and severe cases. He recognized a prognostic significance only in uncomplicated pneumonia, as complicated cases have a severe prognosis anyhow [22]. Two years later, Geissler [23], practicing in Leipzig, confirmed his findings in 425 pneumonia cases with $43 \%$ herpes. Bleuler [24], who defended a thesis on the subject in Zürich, also was able to demonstrate the prognostic significance. Trousseau mentioned the association but did not write on a prognostic significance. Osler [2] is already mentioned in the Introduction of this article. It was mentioned by Church and Peterson [17, p. 81] to be of significance, not clarifying whether they aimed at the diagnostic or prognostic significance.

Two large series were published in the 20th century. Glantzberg [25] found herpes in $17.5 \%$ of pneumonia cases; prognosis was better in those with herpes. One of the most extensive studies on this association, including 412 cases, was published by Ole Sylvest in 1952 [26]. Herpes was found in $20 \%$ of lobar pneumonia and in $10 \%$ of bronchopneumonia. Mortality in the period 1933-1944 was higher in cases without herpes: among 1,754 patients with broncho- or lobar pneumonia, $15.6 \%$ had herpes and mortality was $4 \%$. In the nonherpes group, mortality was $13.5 \%$. Looking at the daily distribution of the appearance of herpes in association with mortality, he was able to conclude that "the apparent better prognosis of a pneumonia patient, whose illness is combined with herpes, is real and not due to a possible outbreak of herpes not having had sufficient time to develop before the death of a patient." He was also able to exclude the possibility that herpes was associated with younger age at which prognosis for pneumonia is better. Next to the prognostic significance, Sylvest [26], based on his results, also included that "every febrile patient with herpes invariably ought to undergo a thorough examination of the lungs."

\section{HL: Pathogenetic or Symbiosis?}

In more recent medical literature, the suggested protective action of HL has not been described anymore. Could this be due to the introduction of antibiotics to treat bacterial meningitis and pneumonia since the late 1940s? Or, is HL just related to fever and should all these

History of Herpes Labialis in Bacterial Meningitis

observations be explained by the combination with a bias with respect to the timing of the herpes recurrence, despite the figures presented by Sylvest [26] that argue against a bias?

A few interesting articles appeared on the possible protective effects of herpesviruses (simplex), including an article in Nature[27], in which the authors "show that herpesvirus latency also confers a surprising benefit to the host." In their mouse studies with herpesviruses similar to human Epstein-Barr virus and Cytomegalovirus, they found resistance against infection with Listeria monocytogenes and Yersinia pestis. The protection was not antigen specific but associated with prolonged production of antiviral cytokine interferon- $\gamma$ and systemic activation of macrophages. They suggested that latency of the viruses upregulates the basal activation state of innate immunity against subsequent infections. Although latency is different from actual recurrence, their findings could fit the historical observations presented above.

\section{Statement of Ethics}

The author has no ethical conflicts to disclose.

\section{Disclosure Statement}

The author has nothing to disclose.

\section{Funding Sources}

The author did not receive any funding.

References

Eur Neurol 2020;83:105-110 DOI: $10.1159 / 000506681$
1 Morton R. Pyretologia, pars altera. London: Smith \& Walford; 1694.

2 Osler $\mathrm{W}$. The principles and practice of medicine. New York: Appleton; 1893.

3 McHenry LC. Garrison's history of neurology. Springfield, IS: Thomas; 1969.

4 Norman JM. Morton's medical bibliography. 5th ed. Aldershot, Hants: Scolar Press; 1991.

5 Koehler PJ, Stahnisch FW. Three twentiethcentury multiauthored neurological handbooks: a historical analysis and bibliometric comparison. J Hist Neurosci. 2014;23:1-30.

6 Stahnisch FW, Koehler PJ. Three 20th-century multiauthored handbooks serving as vital catalyzers of an emerging specialization: a case study from the history of neurology and psychiatry. J Nerv Ment Dis. 2012;200:106775. 
7 Finkelnburg R. Die erkrankungen der meningen. In: Lewandowsky M, editor. Handbuch der neurologie. Zweiter band, spezielle neurologie I. Berlin: Springer; 1911, p. 1078-161.

8 Pette H. Erkrankungen der Hüllen des zentralnervensystems. Pachymeningitis und leptomeningitis. In: Bumke O, Foerster O, editors. Handbuch der neurologie. Zehnter band spezielle neurologie II. Berlin: Springer; 1936, p. 268-412.

9 Levin S, Harris AA, Sokalski SJ. Bacterial meningitis. In: Vinken PJ, Bruyn GW, Klawans HL, editors. Handbook of clinical neurology. Infections of the nervous system. Amsterdam: North-Holland Publishing Company; 1978. Vol. 33; p. 1-19.

10 Hirsch A. Die meningitis cerebro-spinalis epidemica. Berlin: Hirschwald; 1866.

11 Uiterwijk A, Koehler PJ. A history of acute bacterial meningitis. J Hist Neurosci. 2012;21: 293-313.

12 Vieusseux G. Mémoire sur la maladie qui a règné à Genève au printemps de 1805. J Médecine, Chirurgie, Pharmacie, etc. 1806;11: $163-82$.

13 Parent-Duchatelet AJB, Martinet L. Recherches sur l'inflammation de l'arachnoide. Cérébrale et spinale. Paris: Crevot; 1821.

14 Trousseau A. Clinique médicale de l'Hôtel Dieu de Paris. 2nd ed. Paris: J.-B. Baillière et fils; 1865 . Vol. 1.

15 Tourdes G. Histoire de l'épidémie de méningite cérébro-spinale observée à Strassbourg en 1840-1844. Strasbourg: Derivaux; 1845.

16 Oppenheim H. Lehrbuch der nervenkrankheiten. Berlin: Karger; 1894.

17 Church A, Peterson F. Nervous and mental diseases. Philadelphia: Saunders; 1899.

18 Hirsch A. Ueber die Epidemie von Meningitis cerebro-spinalis während des Frühlings 1864 in Bromberg. Nach schriftliche Mittheilungen des Herrn Dr. Salomon in Bromberg. Berlin Klin Wochenschr. 1865;2:328-30.

19 Forget CP. Relation de l'épidémie de méningite encéphalorachidienne, observée à la clinique médicale de la faculté de Strasbourg, en 1841. Gaz Méd. 1842;10:225-32.
20 Maillot FC. Recherches sur la méningite cérébro-spinale épidémique. Gaz Méd. 1848;3(3): 969-73.

21 Lévy M. Histoire de la méningite cérébro-spinale observée au Val-de-Grace en 1848 et 1849. Gaz Méd. 1849;3(4):830-7.

22 Drasche A. Ueber das Verhalten und die prognostische Bedeutung des Herpes bei der Lungen-Entzündung. Oest Ztschr Pract Heilkd. 1859;5:828-9.

23 Geissler HTh. Ueber die prognostische Bedeutung des Herpes bei der Pneumonie. Arch Heilkd. 1861;2:115-38.

24 Bleuler R. Klinische Beobachtung über Pneumonie. Dissertation. Zürich: Zürcher \& Furrer; 1865.

25 Glantzberg H. Über die prognostische Bedeutung des Herpes bei Grippe und Pneumonie. Dissertation. Berlin: 1936.

26 Sylvest O. Herpes labialis as a complication to medical diseases, with particular regard to the prognosis of pneumonia. Acta Med Scand. 1952;141:385-98.

27 Barton ES, White DW, Cathelyn JS, Brett-McClellan KA, Engle M, Diamond MS, et al. Herpesvirus latency confers symbiotic protection from bacterial infection. Nature. 2007;447: 326-9.

28 Bright R, Addison T. Elements of the practice of medicine. London: Longman et al; 1839. Vol. 1.

29 Romberg MH. A manual of the nervous diseases of man. Sieveking EH, Transl. \& editor. London: Sydenham Society; 1853. Vol. II.

30 Reynolds JR. The diagnosis of diseases of the brain, spinal cord, nerves and their appendages. London: Churchill; 1855.

31 Eulenburg A. Lehrbuch der Nervenkrankheiten. Zweite völlig umgearbeitete und erweiterte Auflage. Berlin: August Hirschwald; 1878.

32 Rosenthal M. A clinical treatise on the diseases of the nervous system. Putzel L, Transl. New York: Wood; 1879. Vol. II.

33 Wernicke C. Lehrbuch der Gehirnkrankheiten für Aerzte und Studirende (3 vols). Kassel: Fischer; 1881-3.
34 Hammond WA. Treatise on diseases of the nervous system. 2nd ed. (revised and corrected). New York: Appleton; 1872.

35 Dana CL. Textbook on nervous diseases. New York, NY: Wood; 1892.

36 Gowers WR. A manual of diseases of the nervous system. 2nd ed. London: Churchill; 1893. Vol. II.

37 Dercum FX, editor. A textbook on nervous diseases by American authors. Philadelphia: Lea Brothers; 1895

38 Mills CK. The nervous system and its diseases. Philadelphia: Lippincott; 1898.

39 Sachs B. A treatise on the nervous diseases of children for physicians and students. 2nd ed. New York: Wood; 1905.

40 Starr MA. Organic and functional nervous diseases. 2nd ed. New York and Philadelphia: Lea Brothers and Company; 1907.

41 Marie P. La pratique neurologique. Paris: Masson; 1911.

42 Dejerine J. Sémiologie des affections du système nerveux. 2nd ed. Paris: Masson; 1914.

43 Jelliffe SE, White WA. Diseases of the nervous system. A textbook of neurology and psychiatry. 2nd ed. Philadelphia: Lea \& Febiger; 1917.

44 Bouman L, Brouwer B, editors. Leerboek der zenuwziekten. Part II. Haarlem: Bohn; 1923. Vol. 1.

45 Strümpell A, Seyfarth C. Lehrbuch der speziellen Pathologie und Therapie der inneren Krankheiten. 29th ed. Leipzig: Vogel; 1930. Vol. 1.

46 Gans A. Leerboek der neurologie. Leiden/ Amsterdam: Stenfert Kroese; 1934.

47 Wilson SAK, Bruce AN (editor). Neurology. Vol. 2. London: Arnold; 1940.

48 Frentzel. Ueber eine Epidemie von Meningitis cerebro-spinalis. Berlin Klin Wochenschr. 1864;1:213-7; 226-8.

49 Wunderlich CA. Weitere Mittheilungen über Fälle von epidemischer Cerebrospinal Meningitis in Leipzig. Arch Heilkd. 1865;6:26884.

50 Ziemmsen Hvon, Hess F. Klinische Beobachtungen über Meningitis cerebrospinalis epidemica. Dtsch Arch Klin Med. 1866;1:34654 . 